\title{
Labour Mobility - An Adjustment Mechanism in Euroland?
}

Empirical Evidence for Western Germany, France, and Italy

\author{
Patrick A. Puhani* \\ Centre for European Economic Research (ZEW), Mannheim
}

September 1999

Dr. Patrick A. Puhani

ZEW

L7, 1

D-68161 Mannheim

Germany

Tel.: +49621 1235-281

Fax: +49621 1235-225

e-mail:puhani@zew.de

JEL classification: E66, J61, P52

Keywords: European Monetary Union (EMU), euro, labour mobility

*The author is also a Research Affiliate at the Center for Economic Policy Research (CEPR), London, UK, the Institute for the Study of Labor (IZA), Bonn, Germany, and a Research Fellow of The William Davidson Institute at the University of Michigan Business School, Ann Arbor, MI, U.S.A. 


\section{Non-Technical Summary}

Before the $1^{\text {st }}$ of January 1999 it was possible for, say, Italy to make her products more attractive by allowing her currency to devaluate. What is more, the price of the Italian currency could be adjusted within seconds at the world's currency exchanges. Today, Italy has a common currency with the other countries that adopted the euro. If by some shock Italian exports were overpriced in relation to, say, German products, an adjustment of the exchange rate would not be possible any more to restore equilibrium. If prices remain rigid, factor mobility is the most important substitute for the exchange rate as a means of adjustment between two regions in a currency union. It is the aim of this paper to evaluate whether labour in Europe is mobile enough to accommodate shocks to unemployment and incomes.

To this end, we estimate the migratory response with respect to changes in unemployment and income on the basis of regional panel data provided by Eurostat, the statistical office of the European Union. The countries investigated are Western Germany, France, and Italy. The statistical analysis indicates that migration responds to changes in unemployment, but the effect of income is insignificant. Simulation results show that at a maximum 30 percent of an increase in the number of unemployed persons are accommodated by a migratory response in Germany one and a half years after the shock. The corresponding estimates for France and Italy are much lower at 8 percent and 4 percent, respectively. In the case of Western Germany, it takes at least four years until more than half of a shock to unemployment is accommodated by migration.

As a result, labour mobility cannot act as a sufficient adjustment mechanism to asymmetric shocks in Euroland in the short run. Policy measures to improve European labour mobility would have to include profound changes like the coordination of the tax and social insurance systems and the definition of a common language. Such measures are not planned in the near future which means that labour mobility will remain low in Europe. As a consequence, Euroland has to live with larger and more persistent structural problems than the United States, where labour is more mobile.

In theory this need not be a problem for the euro, as regional inequalities in Euroland are not per se a problem for a common currency. However, if Europeans keep up comparatively high welfare payments as well as regional policies, the euro may increase the demand for public funds on a national, but maybe also on a European level. The consequences of monetary union combined with deficient migration might therefore be higher taxes. 


\begin{abstract}
The purpose of this paper is to evaluate whether labour mobility is likely to act as a sufficient adjustment mechanism in the face of asymmetric shocks in Euroland.

To this end, we estimate the elasticity of migration with respect to changes in unemployment and income on the basis of regional panel data provided by Eurostat, the statistical office of the European Union. Regression results are provided for Western Germany, France, and Italy.

It is shown that labour mobility is highest in Germany, followed by France, and Italy. However, even in Germany, the accommodation of a shock to unemployment by migration takes several years.

We conclude that labour mobility is extremely unlikely to act as a sufficient adjustment mechanism to asymmetric shocks in Euroland.
\end{abstract}

\title{
Acknowledgement
}

This research was undertaken with support from the 'Deutsche Post - Stiftung' (German Mail Foundation) under the project 'Arbeitsmarkteffekte der Europäischen Währungsunion' (Labour Market Effects of European Monetary Union). I thank my collegues Bernhard Boockmann, Thiess Büttner, Herbert S. Buscher, François Laisney, Claudia Müller, and Viktor Steiner for helpful comments. Furthermore, I would like to thank Werner Grünewald, Eurostat Luxembourg, for helpful information on Eurostat's Regio databank. I received excellent research assistance from Stefan Leiderer. All remaining errors are my own. 


\section{Introduction}

Is labour mobility likely to adjust for asymmetric shocks in Euroland? This is the central question to be addressed in this paper. Now that most countries in the European Union have a common currency, they cannot use independent monetary policies any more as a means of adjustment. With no more exchange rates and equal interest rates between them, some other mechanism has to take effect when the supply and demand of a country's goods are in imbalance.

Mundell (1961) suggests that the degree of external versus internal factor mobility is decisive for defining optimum currency areas: he argues that flexible exchange rates work best if the world can be divided into currency areas within which factor mobility is very high, but between which factor mobility is very low. The lack of factor mobility between the currency regions can then in the face of shocks be compensated by exchange rate alignments. For European Monetary Union, Mundell's (1961) argument means that the euro zone (Euroland) would be more optimal than the former national currency zones, if the factors of production were more mobile within Euroland than within nation states, given the same levels of asymmetric shocks within the respective currency zones. Put differently: on the one hand, a high degree of factor mobility within Euroland is required to compensate for the loss of the exchange rate as an adjustment mechanism in the face of asymmetric shocks between Euroland's nation states. On the other hand, tough, it is doubtful whether former national currencies were appropriate shock absorbers given asymmetries and low factor mobilities within European nation states.

Previous research concludes that the shocks experienced by the European Union are more asymmetric as those in the United States or in Germany (Bayoumi and Eichengreen, 1993; Funke, 1997), where smaller countries are especially hit by asymmetric shocks (Buscher, 1999). Although economic integration may cause these asymmetries in Euroland to decline, differences in tax and social security systems as well as comparative advantage may well lead to a type of integration which creates more asymmetries. Which effect will dominate is an empirical question for the future. For now, it seems safe to assume that the need to adjust for asymmetric shocks is greater in Euroland than in the United States or in the former currency areas of the euro zone. But although there is some weak evidence that independent monetary policies of Euroland's nation states could in the past be used to achieve more economic convergence (Müller and Buscher, 1999a), there is also empirical evidence for the hypothesis that the volatility of Euroland's former exchange rates had a destabilising effect on unemployment rates (see Müller and Buscher, 1999b, and the studies cited therein). 
Hence it is by no means clear that the loss of the exchange rate flexibility between Euroland's former currencies is economically undesirable in itself (Franz, 1998). Nevertheless, a high degree of factor mobility will be conducive to the wellfunctioning of Europe's currency union. Müller and Heinemann (1999) show that exchange rate volatility led to a smaller degree of capital mobility in Euroland in the past. Therefore, the euro is likely to increase the degree of capital mobility. Another factor likely to raise capital mobility is the fact current account targets to stabilise national exchange rates become unnecessary for nation states within the euro zone. This allows a higher discrepancy between savings and investments and hence higher capital mobility than before currency union.

The purpose of this paper is to investigate how far labour mobility has the potential to act as a means of adjustment. Our empirical analysis presents estimates of migration-induced population changes due to changes in unemployment or incomes in Western Germany, France, and Italy. Generally, our data do not allow us to distinguish between internal and external migration (Italy is an exception). Nor are there data on migration between regions belonging to different European nation states. Therefore, Mundell's (1961) criterion for an optimum currency area, namely the comparison of internal versus external factor mobilities between the old and new currency areas, cannot be implemented empirically. Nevertheless, the size of the estimates from the approach taken here allows a judgement on the short-run equilibrating potential that labour mobility might have in the investigated countries today. It will be seen that this potential is rather low and is likely to remain so in the near future.

The paper is structured as follows. Section 2 summarises empirical studies on labour mobility in Europe. In Section 3, the size of the migratory response to unemployment and income differentials in Western Germany, France, and Italy is estimated on the basis of the most recent available data from Eurostat, the statistical office of the European Union. Our results are summarised in Section 4, where some hypotheses on the future development of labour mobility in Europe as well as policy options are presented. 


\section{Previous Work on Labour Mobility in Europe}

Official European statistics do not collect data on migration between regions of different nation states. Therefore, previous studies on labour mobility in Europe either only give rough descriptions of international compared to intranational migration, or compare interregional migration within specific European nation states with interregional migration in the United States. Studies which make comparisons between countries are summarised in Table 1 in chronological order.

The articles which present descriptive statistics of international versus intranational migration are OECD (1986), Straubhaar (1988), De Grauwe and Vanhaverbeke (1993), and Gros (1996). The results from the observations of these statistics can be summarised as follows: total migration as a share of total population is generally lower in European countries than in the United States. Also, migration in Europe is lower than in Australia, Canada, and Japan. Moreover, (im)migration flows in(to) the European union are of the same order as or higher than interregional migration flows in European countries. This means that labour mobility in Europe is just as driven by immigration as it is by migration within Europe. In addition, migration within Europe is largely migration within European nation states rather than between them. Comparing interregional migration within different European nation states, it is shown that in southern countries (Italy and Spain) interregional migration is less than half as large as in northern ones (Western Germany, France, Netherlands, UK).

To sum up the prima facie evidence on migration flows in Europe, it seems rather clear that mobility in European nation states lacks behind mobility in other nation states. As mobility between European nation states is much lower as within them, it is plausible to assume that labour mobility cannot be an adequate adjustment mechanism for labour market disequilibria in Euroland. However, it may well be the case that the cause of low mobility in Europe is the lack of economic incentives to migrate. In this case, the conclusion that European labour mobility is too low to act as an adjustment instrument would be wrong. What is decisive to the answer of this question is not the total migration flows between European regions, but the elasticities of migration with respect to economic outcomes such as wages and unemployment rates.

The correlation between migration flows and economic variables has been investigated by Weidlich and Haag (1988), Eichengreen (1993), Chies (1994), Barro and Sala-i-Martin (1995), Decressin and Fatás (1995), Gros (1996), and the European Commission (1998). The studies show that economic variables like wage and unemployment differentials are indeed important determinants of migration flows. As expected, high wages favour immigration, whereas high unemployment rates 
favour emigration. However, migration flows generally take years to absorb economic shocks. Migratory responses to labour market outcomes also vary between countries. Investigations based on regression analysis demonstrate that workers in the United States (and Japan) are more mobile than Europeans within their own nation states. Comparing European countries, mobility in Western Germany is higher than in the UK, where it is higher than in Italy. In general, regional employment shocks in Europe are mainly accommodated by short-run changes in the labour force participation rate, whereas they trigger migration flows in the United States.

To sum up, European migratory responses to unemployment and wage differentials between and within nation states are lower than in the United States. In general, previous estimates suggest that it takes more than a decade for migration to adjust for shocks to unemployment. This holds even for Western Germany, where labour seems to be more mobile than in Italy or the UK (before 1990) (see also Büttner, 1999a, for Western Germany; Attanasio and Padoa Schioppa, 1991, for Italy; Pissarides and McMaster, 1990, for the UK). Moreover, Decressin (1994) shows with German data that the migratory response with respect to unemployment is lowest when unemployment is generally high. This means that mobility is low when it is most needed.

Unfortunately, with one exception, the studies surveyed in Table 1 do not attempt to pin down the migratory response to unemployment or wage movements by a number which is easy to interpret. Although Eichengreen (1993) estimates a coefficient on the lagged unemployment rate with the immigration rate as the dependent variable, no sample means are provided in his paper, so that a statement ' 1 percent more unemployed people causes $x$ percent of the population to migrate' cannot be made from his paper without ad hoc assumptions. The same is true for the contribution of Barro and Sala-i-Martin (1995). Decressin and Fatás (1995), on the other hand, estimate that in the European Union almost zero percent of a shock in labour demand are reflected by migration one year after the shock. Two, three, and four years after the shock, the shares are 27, 45, and 80 percent, respectively. By contrast, in the United States 52 percent of a shock in labour demand are accommodated by migration already in the first year after the shock.

Using a somewhat different methodology, smaller regional units, and more recent data than Decressin and Fatás (1995), we will estimate the short-run response of migration to changes in unemployment rates and incomes in the following section. 
Table 1: Summary of Comparative Empirical Studies

\begin{tabular}{|c|c|c|c|c|}
\hline Study & Countries & Data & Methodology & Main Results \\
\hline OECD (1986) & $\begin{array}{c}\text { Australia, } \\
\text { Canada, USA, } \\
\text { Japan, } \\
\text { CH, D(W), } \\
\text { England/Wales, } \\
\text { F, N, S, SF }\end{array}$ & $\begin{array}{l}1965-1983 \text { panels for } 8 \text { (Australia), } \\
12 \text { (Canada), } 51 \text { (USA), } 47 \text { (Japan), } \\
\text { 26 (CH), } 11 \text { (D(W)), } 8 \\
\text { (England/Wales), } 21 \text { (France), } 19 \\
\text { (N), } 24(\mathrm{~S}), 12 \text { (F) regions }\end{array}$ & $\begin{array}{l}\text { Comparison of interregional } \\
\text { migration rates within countries } \\
\text { over time }\end{array}$ & $\begin{array}{l}\text { Interregional migration is highest in the USA, } \\
\text { Australia, Canada, and Japan, lowest in Europe } \\
\text { Over time, interregional migration has declined by } \\
\text { between a quarter and a third in Europe and Japan }\end{array}$ \\
\hline Straubhaar (1988) & $\mathrm{EU}$ & $1958-1980$ & $\begin{array}{l}\text { Comparison of intra-EU and extra- } \\
\text { EU migration flows }\end{array}$ & $\begin{array}{l}\text { The share of extra-EU migration in total migration } \\
\text { flows rose from one third to two thirds }\end{array}$ \\
\hline $\begin{array}{l}\text { Weidlich and Haag } \\
\text { (1988) }\end{array}$ & $\begin{array}{l}\text { Canada, D, F, } \\
\text { Israel, I, S }\end{array}$ & $\begin{array}{c}\text { 1961-1982 (Canada), } \\
\text { 1960-1983(D), } \\
\text { 1954-1982 (F), } \\
1965-1980(\text { Israel) } \\
\text { 1965-1982 } \\
1968-1982(\mathrm{~S}) \\
\text { panels for } 10 \text { (Canada), } 11 \text { (D), } 21 \\
\text { (F), } 14 \text { (Israel), } \\
20(\mathrm{I}), 8 \text { (S) regions }\end{array}$ & $\begin{array}{l}\text { Regression of 'regional utilities' on } \\
\text { socio-economic variables; } \\
\text { 'regional utilities' are obtained from } \\
\text { a dynamic model of interregional } \\
\text { migration with microeconomic } \\
\text { foundations }\end{array}$ & $\begin{array}{l}\text { Income and (un)employment variables are key factors } \\
\text { explaining regional preferences } \\
\text { D and S are closer to equilibrium population } \\
\text { distribution than Canada and I } \\
\text { For Canada, D (I, S) the trend is towards slower } \\
\text { (faster) adjustment to equilibrium } \\
\text { Generally, adjustment is slow in relation to the } \\
\text { frequency of shocks }\end{array}$ \\
\hline $\begin{array}{l}\text { De Grauwe and } \\
\text { Vanhaverbeke } \\
\text { (1993) }\end{array}$ & $\begin{array}{l}\mathrm{D}(\mathrm{W}), \mathrm{E}, \mathrm{F}, \mathrm{I}, \mathrm{NL} \\
\mathrm{UK}\end{array}$ & $\begin{array}{l}\text { 1975-1987 internal migration rates } \\
\text { for } 11(\mathrm{D}(\mathrm{W})), 16(\mathrm{E}), 9(\mathrm{~F}) \text { regions, } \\
11(\mathrm{I}), 4(\mathrm{NL}) \text {, and } 11(\mathrm{UK}) \text { regions }\end{array}$ & $\begin{array}{l}\text { Comparison between countries of } \\
\text { internal regional migration rates }\end{array}$ & $\begin{array}{c}\text { Interregional mobility in the southern }(\mathrm{E}, \mathrm{I}) \text { countries } \\
\text { is less than half as large as in the northern ones } \\
(\mathrm{D}(\mathrm{W}), \mathrm{F}, \mathrm{NL}, \mathrm{UK}) \text { despite higher income differentials } \\
\text { in the South }\end{array}$ \\
\hline & & $\begin{array}{l}\text { Stock of the countries' immigrants } \\
\text { from and emigrants to the rest of } \\
\text { the EU in } 1984\end{array}$ & $\begin{array}{l}\text { Comparison of the stock of } \\
\text { migrants (cumulated external } \\
\text { migration) with the internal } \\
\text { (regional) migration rate }\end{array}$ & $\begin{array}{l}\text { External cumulated migration is smaller than annual } \\
\text { internal migration }\end{array}$ \\
\hline Eichengreen (1993) & $\begin{array}{c}\text { GB } \\
\text { I } \\
\text { USA }\end{array}$ & $\begin{array}{l}1962-1985 \text { panels for } 9(\mathrm{~GB}, \mathrm{USA}) \\
\text { and } 6 \text { (I) regions }\end{array}$ & $\begin{array}{l}\text { Regression of net immigration rate } \\
\text { on lagged net migration rate, lagged } \\
\text { change in relative (to national) } \\
\text { wages, and lagged relative } \\
\text { unemployment rate }\end{array}$ & $\begin{array}{l}\text { Immigration is positively related to high wages and } \\
\text { negatively to high unemployment rates } \\
\text { Migratory responses are larger in the USA than in GB } \\
\text { and I }\end{array}$ \\
\hline & & & Tests for cointegration between & Regional and national unemployment rates are \\
\hline
\end{tabular}




\section{Table 1: Summary of Comparative Empirical Studies (ctd.)}

\begin{tabular}{|c|c|c|c|}
\hline Chies (1994) & $\begin{array}{c}\text { D, F, } \\
\text { E, GR, I, P, TK }\end{array}$ & $\begin{array}{c}\text { 1961-1990 time series for each } \\
\text { country }\end{array}$ & $\begin{array}{l}\text { Regression of emigration rate from } \\
\text { E, GR, I, P, TK to D, F on income } \\
\text { and unemployment differentials }\end{array}$ \\
\hline $\begin{array}{l}\text { arro and Sala-i- } \\
\text { Martin (1995) }\end{array}$ & $\begin{array}{l}\text { D, E, F, GB, I } \\
\text { USA } \\
\text { Japan }\end{array}$ & $\begin{array}{c}\text { 1990-1990 (USA), 1955-1990 } \\
\text { (Europe, Japan) panels for 51 US } \\
\text { states, 46 Japanese prefectures, and } \\
11 \text { (D), } 17 \text { (E), } 21 \text { (F), } 20 \text { (I) regions } \\
\text { in European countries }\end{array}$ & $\begin{array}{l}\text { Regression of net migration rate on } \\
\text { per capita income, weather } \\
\text { conditions, and population density }\end{array}$ \\
\hline $\begin{array}{l}\text { Decressin and } \\
\text { Fatás (1995) }\end{array}$ & $\begin{array}{l}\text { EU } \\
\text { USA }\end{array}$ & $\begin{array}{l}\text { 1975-1990 panels for } 51 \text { US states } \\
\text { and } 51 \text { EU regions }\end{array}$ & $\begin{array}{l}\text { Regression of dynamic system of } \\
\text { equations with relative (to EU / US) } \\
\text { employment innovations, } \\
\text { employment rates, and participation } \\
\text { rates }\end{array}$ \\
\hline Gros (1996) & $\mathrm{EU}$ & 1992 cross section of EU regions & $\begin{array}{c}\text { Comparison of immigration rates } \\
\text { into member states with those } \\
\text { between regions within member } \\
\text { states } \\
\text { Comparison of the correlations } \\
\text { between interregional migration and } \\
\text { owner occupancy levels }\end{array}$ \\
\hline $\begin{array}{l}\text { European } \\
\text { ommission (1998) }\end{array}$ & $\begin{array}{l}\text { EU } \\
\text { USA }\end{array}$ & $\begin{array}{l}\text { EU: NUTS } 2 \text { regional data } \\
\text { USA: } 9 \text { census regions }\end{array}$ & $\begin{array}{l}\text { Comparison of the correlations } \\
\text { between net migration rates and } \\
\text { unemployment rates }\end{array}$ \\
\hline
\end{tabular}

cointegrated in GB and I, but not in the USA

Income differentials play a role for the migration from $\mathrm{E}$ and $\mathrm{P}$ to $\mathrm{F}$, and from $\mathrm{E}$ and $\mathrm{I}$ to $\mathrm{D}$

Unemployment differentials drive the migration from GR and I to D and from I to F

Income has a much smaller effect on migration in Europe than in the USA or Japan

Migration plays only a minor role in the convergence

$$
\text { of incomes }
$$

A region-specific employment shock in the EU as well as in EU nation states (in the USA) is in the short-run mainly absorbed by the participation rate (migration between regions)

Mobility is higher in Western Germany than in the UK and Italy

Existence of natural relative unemployment rates at the regional level in both the EU and the USA

The immigration rate into EU member states and inter-regional migration are roughly of the same order

Countries with higher owner occupancy levels have lower interregional migration rates

However, the UK is an outlier with a comparatively high interregional migration rate

The correlation between unemployment rates and migration is greatest in I, SF, UK, USA

Notes: abbreviations: CH: Switzerland; D: Germany; D(W): Western Germany; E: Spain; EU: European Union; F: France; GB: Great Britain; GR: Greece; I: Italy; N: Norway; NL: Netherlands; P: Portugal; S: Sweden; SF: Finland; TK: Turkey; USA: United States of America; UK: United Kingdom 


\section{Empirical Analysis}

In this section, we estimate the short-run impact of alterations in unemployment rates and incomes (gross domestic product, GDP) on migration. The reason we use data on GDP and not on wages is that complete and consistent wage series are not available. Our model is described in Section 3.1. Section 3.2 introduces the data we use and presents some stylised evidence on convergence of unemployment rates and GDP in Euroland on the basis of descriptive statistics. Finally, we discuss our estimation results in Section 3.3.

\subsection{Model Specification}

Our aim is to estimate the elasticity of the migration-induced population growth factor in a region with respect to a ceteris paribus change in the number of the unemployed or the level of income. In analogy to the Todaro migration model (see, e.g., Todaro, 1980), we assume that migration is affected by the expected level of income that can be obtained at home in relation to the level that can be obtained elsewhere. Thus not only the average income of a region is decisive for its attractiveness for migrants, but also the likelihood of finding a job in that region. This likelihood may be proxied by the unemployment rate. We therefore assume the following model for the migration-induced population growth factor:

$$
\frac{m i g_{i t}+\text { pop }_{i t-1}}{\text { pop }_{i t-1}}=A_{i t} \frac{u_{i t-1}^{\alpha_{1}} y_{i t-1}^{\alpha_{2}}}{u_{n t-1}^{\alpha_{1}} y_{n t-1}^{\alpha_{2}}}
$$

where mig denotes net (im)migration, pop population, $u$ the unemployment rate, and $y$ income (GDP). $A$ is a some constant. The indices $i, n$, and $t$ describe the individual region, the nation it belongs to, and time (in years), respectively.

Taking natural logarithms on both sides of the equation, a log-linear equation can be derived which may be estimated:

$$
\ln \frac{m i g_{i t}+\operatorname{pop}_{i t-1}}{\text { pop }_{i t-1}}=\alpha_{0}+\alpha_{1} \ln u_{i t-1}-\ln u_{n t-1}+\alpha_{2} \ln y_{i t-1}-\ln y_{n t-1}+\mu_{i}+\eta_{t}+\varepsilon_{i t} \text {. }
$$

where $\ln A_{i t}=\alpha_{0}+\mu_{i}+\eta_{t}+\varepsilon_{i t}$. To give an example of how this equation can be interpreted, $\alpha_{1}$ is the migration elasticity with respect to the number of unemployed persons. This is to say, if the number of unemployed persons in a region increases by 1 percent, the population in that region will ceteris paribus increase by $\alpha_{1}$ percent due to migration. The coefficient on income can be interpreted analogously. Note that 
separate coefficients for the country-specific variables $\ln u_{n t-1}$ and $\ln y_{n t-1}$ are not identifiable if time-specific effects are estimated for each year, as the variables $\ln u_{n t-1}$ and $\ln y_{n t-1}$ only have a variation in the time-series, but not in the cross-section dimension.

\subsection{Data and Descriptive Statistics}

We use regional data at the NUTS2 level from the Regio 98 databank of Eurostat, the statistical office of the European Union (NUTS stands for nomenclature of territorial units for statistics, see Figure 1 in the appendix). This databank contains inter alia data on the population, births, deaths, unemployment (rates), and the gross domestic product. Data on net migration can be retrieved for all countries as the population change plus deaths minus births. The net migration data retrieved in this way also includes external migration. In addition, there are data on internal migration for some countries at the NUTS2 level.

Due to the extrapolations by which population statistics are obtained between population censuses, we sometimes observe huge jumps in the measured migration rate when a population census take place. Although a measurement error in the dependent variable does not lead to biased estimation results unless the measurement error is correlated with the exogenous variables, we decided to exclude years when the observed migration showed unrealistic spikes. The Spanish data are excluded from the analysis completely for that reason. Correspondence with Eurostat confirmed that the measurement errors are particularly large for Spain.

Panels of reasonable size are only available for the larger countries of Euroland. We thus concentrate our analysis on Western Germany, France, and Italy. Figure 2 to Figure 5 in the appendix show the development of the migration-induced population growth factor for these countries. Figure 2 to Figure 4 plot the migration-induced population growth factors where migration includes external migration. The graphs show that Western Germany experienced a huge immigration wave in the beginning of the 1990s (cf. Velling, 1995; Zimmermann, 1995). This is due to the fall of the iron curtain which was followed by mass immigration of Germans living in Eastern Germany or other formerly communist states. In France, the average population growth factor does not seem to have changed much over time. In Italy, we observe a slight rise in the beginning of the 1990s, but the degree of the increase is not comparable to the one shown for Western Germany.

As we also have data on internal migration at the NUTS2 level for Italy, a comparison of total migration with only internal migration can be made from Figure 4 and Figure 5. In the latter, the year 1990 had to left out because of large spikes for some regions that are due to measurement errors (information from Eurostat). At first sight, 
the two figures for Italy look rather distinct. However, a closer look reveals that the ordering of regions according to the migration-induced population growth factor is very similar in both data sources.

Summary statistics for the data panels of both the dependent and the independent variables in our model are provided in Table 4 to Table 7 in the appendix. Comparing the average population size of the regions between the countries (about in the middle of each table), it is found that Western Germany has - on average -smaller regions (population around 2 million persons) than France or Italy (around 2.7-2.8 million persons). The German regions are on average also smaller in territory than the French or Italian ones. This observation carries some importance, as the share of people leaving a smaller region is likely to be larger than the share of people leaving a larger region given the same relative shock. The reason is that distance is likely to play a role as a cost factor in the migration decision of individuals. When regions are smaller, it will therefore be less costly to move to another region. As we cannot control for these smaller distances within our framework, it should be borne in mind that there is an a priori reason to believe that the estimated migration elasticities will be somewhat higher for Western Germany than for France or Italy due to the smaller size of the German regions.

Because the Hausman (1978) test rejected the random effects model in all cases, we will only present fixed effects models in Section 3.3 below. As the fixed effects estimator only uses the within variation in the panel data, it is important to observe how much variation is lost by neglecting the between variation. Turning to the dependent variable first, the within variation is about three times as large as the between variation for Western Germany, but only around half as large for France and Italy. Hence for the latter two countries, a lot of information is lost applying the fixed effects estimator. For Western Germany, it should be kept in mind, though, that a large share of the within variation is likely to be due to external migration. It is shown that Western Germany (Table 4) has by far the highest mean migration-induced population growth factor, followed by Italy (Table 6) and France (Table 5).

Turning to the exogenous variables, the within variation of the relative unemployment rate is only a third or a half of the between variation. Again for Western Germany the problem is less pronounced than for France and Italy. As concerns relative GDP, the within variation is around a third (Western Germany), an eighth (France), or a thirteenth (Italy) of the between variation. Hence for GDP the within variation is so small that it would not be surprising to obtain insignificant coefficients on this variable in a regression analysis using the fixed effects estimator. Only the variables indicating the change in the unemployment rate and the change in GDP have a greater within than between variation. These variables will be added to the regression as exogenous variables. Summary statistics for the population, the absolute number of 
the unemployed, the unemployment rate, and the level of GDP are reported to inform the interested reader.

Before the presentation of the estimation results, we provide some descriptive evidence on labour market outcomes in Euroland. Suppose that labour mobility were sufficiently high in Europe to act as an adjustment mechanism between European regions. Then we would expect that labour market outcomes such as unemployment rates or GDP show some tendency of convergence over time. We therefore plot coefficients of variation in unemployment rates as well as GDP (at purchasing power parities) in Figure 6 and Figure 7. Turning to unemployment rates in Figure 6 first, the coefficients of variation clearly change over time, yet these changes look cyclical rather than outcomes of trends ( $c f$. Baddeley, Martin, and Tyler, 1998). This is true both for the coefficients of variation in the European Union and those for individual nation states. Only reunited Germany has experienced some downward adjustment after the shock of 1992. An interesting observation that can be made from Figure 6 is that the dispersion in unemployment rates in Euroland is comparable to that of Italy or reunited Germany at the time when unemployment soared in Eastern Germany. On the other hand, Spain, a country with extremely high levels of unemployment has nevertheless a dispersion in regional unemployment rates that is comparable to the one of Western Germany, where unemployment has been comparatively low.

As to GDP (Figure 7), we also find that the dispersion amongst the regions of Euroland is comparable to that of Italy. The dispersion in GDP within Western Germany, France, or Spain is markedly lower than in Euroland or Italy. Considering the coefficient of variation of Euroland in the early 1990s, it is shown that only reunited Germany displays a greater regional variation in GDP. However, by the year 1995, the coefficients of variation of reunited Germany, Euroland, and Italy were not very different from each other.

To sum up the descriptive evidence on the dispersion of unemployment rates and GDP in Euroland over time, one can confidently conclude that no pronounced convergence has occurred. This does not necessarily mean that labour mobility does not work as a means of adjustment at all, as there might be large economic shocks that just offset the equilibrating forces of the adjustment mechanism.

The following section will therefore estimate the migration elasticity with respect to unemployment and GDP differentials for Western Germany, France, and Italy.

\subsection{Estimation Results}

The estimation results of the migration-induced population change are reported in Table 2 below. The explanatory power is highest for Western Germany, followed by 
Italy (1) (when total net migration is used), and France. However, the explanatory power for the Italian (2) data on internal migration is the lowest of all equations. This observation gives credence to the view that regional unemployment (and maybe GDP) explains the direction of external migration better than the direction of internal migration. Theoretical considerations are consistent with this result: an immigrant into Italy will face similar transaction costs whether he or she moves to Milan or Naples. Therefore, he or she will go where job opportunities are. For a person living in Naples, it will make a difference whether he or she moves to Milan (positive transaction costs) or stays where he or she lives (no transaction costs). It is therefore plausible that external migrants react stronger to economic incentives within the receiving country than people who already live in that country. This fact might also explain why the explanatory power is highest for Western Germany, which saw a huge immigration wave in the early 1990s.

As can be seen from Table 2, the only economic variable that is significant in all regressions is the relative unemployment rate. The coefficients on relative GDP have the expected sign, but are insignificant (the coefficients on the GDP variables are also jointly insignificant in all equations). As the within variation of this variable is very small, though, the insignificance of the coefficient is not very surprising. With the data at hand, the effect of GDP may perhaps not be estimated with sufficient precision. The point estimates of the coefficients can be interpreted the following way: a ceteris paribus 1 percent rise in the GDP of a West German region leads to a migration-induced population increase of 0.00136 percent in that region.

The interpretation of the coefficients on relative unemployment is similar: a ceteris paribus 1 percent rise in the number of unemployed persons of a West German region leads to a migration-induced population decrease of 0.00809 percent in that region. To make the results more transparent, we have simulated the size of the adjustment through migration in Table 3. To stay with the example of Western Germany, a one percent increase of the number of unemployed persons from the mean value in the sample amounts to 557 additional people in unemployment. According to our estimates, the migration-induced population change of -0.00809 percent amounts to a net emigration of 165 people. Under the assumption that all of the 165 emigrating people are unemployed and immediately find a job outside their original region, migration would be able to adjust for 29.6 percent of the unemployment shock within about 1.66 years (as unemployment is measured in April of the previous year) after the shock. The corresponding figures for France and Italy are much lower at 8.4 and 3.7 percent, respectively. When only internal migration is considered in Italy, the estimate becomes even smaller, viz. 2.7 percent. It should be stressed that these simulations make very strong assumptions by counting every emigrant as an unemployed person who immediately finds a job outside his or her home region. It is likely that some of the migrants are family members that are not unemployed. And it may well be that some more time is needed until the emigrant 
finds a job elsewhere. Hence it follows that the simulated shares of the unemployment shock which are adjusted by migration should be seen as upper bounds for the real shares.

Although there are differences in methodology and data sources, our estimates are in many points consistent with previous results in the literature (see Section 2 above). Like Decressin and Fatás (1995), we find that mobility plays a greater role in Western Germany than in Italy. Eichengreen (1993) also concludes that labour mobility is comparatively low in Italy. Having estimated the accommodating potential of migration to be 30 percent of an unemployment shock at a maximum in Western Germany within 1.66 years after the shock, we conclude with other authors that labour mobility can only be equilibrating in the medium to long run. From our estimates, it would take at least four years in Western Germany until more than half of a shock to unemployment is accommodated by migration. Moreover, it is likely that the geographical location of the large number of external migrants into Western Germany contributes heavily to the comparatively high migration elasticity in this country. If this is the case, the internal migration elasticity might be much lower in Western Germany. This is important, because immigrants to low unemployment regions from outside Germany may even out unemployment differentials between German regions, yet they do not necessarily lower the levels of unemployment in the problem regions.

Therefore, the degree of labour mobility in Europe seems to be too low to act as a mechanism to restore labour market equilibria between European regions in the short run. 
Table 2: Estimation Results of Migration Equations

\begin{tabular}{|c|c|c|c|c|c|c|c|c|}
\hline \multirow[b]{2}{*}{ Variable: } & \multicolumn{2}{|c|}{ Western Germany } & \multicolumn{2}{|c|}{ France } & \multicolumn{2}{|c|}{ Italy (1) } & \multicolumn{2}{|c|}{ Italy (2) } \\
\hline & Coeff. & $\mathrm{t}$ & Coeff. & $\mathrm{t}$ & Coeff. & $\mathrm{t}$ & Coeff. & $\mathrm{T}$ \\
\hline$u_{i t-1} / u_{n t-1}$ & -0.00809 & -5.57 & -0.00354 & -2.06 & -0.00152 & -2.48 & -0.00106 & -2.87 \\
\hline$\left(u_{i t-1} / u_{n t-1}\right)-\left(u_{i t-2} / u_{n t-2}\right)$ & -0.00332 & -1.35 & 0.00159 & 0.75 & -0.00017 & -0.27 & -0.00002 & -0.06 \\
\hline$y_{i t-1} / y_{n t-1}$ & 0.00136 & 0.25 & 0.00857 & 1.50 & 0.00367 & 0.66 & 0.00367 & 1.00 \\
\hline$\left(y_{i t-1} / y_{n t-1}\right)-\left(y_{i t-2} / y_{n t-2}\right)$ & 0.00049 & 0.04 & -0.00494 & -0.80 & -0.00163 & -0.29 & -0.00271 & -0.78 \\
\hline Constant & 0.00191 & 3.20 & 0.00207 & 2.80 & -0.00009 & -0.21 & 0.00002 & 0.08 \\
\hline Fixed time effects & \multicolumn{2}{|c|}{ yes } & \multicolumn{2}{|c|}{ yes } & \multicolumn{2}{|c|}{ yes } & \multicolumn{2}{|c|}{ (yes) } \\
\hline Fixed region effects & \multicolumn{2}{|c|}{ yes } & \multicolumn{2}{|c|}{ yes } & \multicolumn{2}{|c|}{ yes } & \multicolumn{2}{|c|}{ yes } \\
\hline $\mathrm{N}$ & \multicolumn{2}{|c|}{30} & \multicolumn{2}{|c|}{21} & \multicolumn{2}{|c|}{20} & \multicolumn{2}{|c|}{20} \\
\hline $\mathrm{T} / \bar{T}$ & \multicolumn{2}{|c|}{11} & \multicolumn{2}{|c|}{10} & \multicolumn{2}{|c|}{11.95} & \multicolumn{2}{|c|}{9.95} \\
\hline $\mathrm{N}$ & \multicolumn{2}{|c|}{330} & \multicolumn{2}{|c|}{210} & \multicolumn{2}{|c|}{239} & \multicolumn{2}{|c|}{199} \\
\hline $\mathrm{R}^{2}$ within & \multicolumn{2}{|c|}{0.8537} & \multicolumn{2}{|c|}{0.2208} & \multicolumn{2}{|c|}{0.5573} & \multicolumn{2}{|c|}{0.1222} \\
\hline
\end{tabular}

Note: the region 'Corse' has been left out in the calculations for France due an inconsistency in the time series of that region (information from Eurostat Luxembourg).

Source: Regio 98 databank, Eurostat; own calculations.

Table 3: Simulated Effects of 1 Percentage Increase in Number of Unemployed

\begin{tabular}{l|c|c|c|c|c|c}
\hline \hline & Coeff. & $\bar{u} \bar{a}_{i t-1}$ & $\bar{p} \overline{\bar{p}_{i t-1}}$ & $\begin{array}{c}\text { Change in } \\
\text { Unemployment }\end{array}$ & $\begin{array}{c}\text { Migration- } \\
\text { Induced } \\
\text { Population } \\
\text { Change }\end{array}$ & $\begin{array}{c}\text { Unempl. } \\
\text { Adjustment } \\
\text { due to Migr. } \\
(\%)\end{array}$ \\
\hline Western Germany & -0.00809 & 55,710 & $2,035,418$ & 557 & -165 & 29.6 \\
France & -0.00354 & 111,981 & $2,664,092$ & 1120 & -94 & 8.4 \\
Italy (1) & -0.00152 & 115,995 & $2,849,854$ & 1160 & -43 & 3.7 \\
Italy (2) & -0.00106 & 114,180 & $2,850,224$ & 1142 & -30 & 2.7 \\
\hline \hline
\end{tabular}

Note: bars indicate means of variables; $u a$ : number of persons unemployed in thousands; pop: population in thousands; $i$ : region indicator; $t$ : time period (year) indicator; population is measured at the beginning of each year; migration is measured in April of each year;

the region 'Corse' has been left out in the calculations for France due an inconsistency in the time series of that region (information from Eurostat Luxembourg).

Source: Regio 98 databank, Eurostat; own calculations. 


\section{Summary, Outlook, and Policy Options}

\section{Summary}

We have estimated the share of an unemployment increase which is compensated through migration within the first 1.66 years after the shock using the most recent available data for Western Germany, France, and Italy. It turned out that in Western Germany, this share is at a maximum 30 percent. For France and Italy, the figures are only 8 and 4 percent, respectively. Our own estimates as well as previous estimates of other authors suggest that the size of the migratory response to unemployment differentials is so low that it takes several years, if not more than a decade for the regional unemployment inequalities to be evened out by labour mobility. One can thus safely conclude that labour mobility is not an economically significant adjustment mechanism in Europe in the short run. This is true within nation states, but all the more between them. As a consequence, Euroland has to live with larger and more persistent structural problems than the United States, where labour is more mobile.

\section{Outlook}

In theory this need not be a problem for the euro at all. First, it is not clear that the loss of the exchange rate as an adjustment mechanism will on average lead to a greater need for adjustment between European nation states: although there is some weak evidence that independent monetary policies facilitated convergence, it also seems that excessive exchange rate volatility was harmful in the past. Moreover, given that inflation rates are now equal in the euro zone, asymmetric wage-push shocks are likely to subside (Boockmann, 1999; Lauer, 1999). Second, regional inequalities in Euroland are not per se a problem for a common currency. However, it can for the moment be taken for granted that Europeans will at least in the medium run keep up comparatively high welfare payments as well as regional policies. In such a setting, the euro may increase the demand for public funds on a national, but maybe also on a European level ( $c f$. Büttner, 1999b). The consequences of monetary union combined with deficient migration might therefore be higher taxes. Clearly, higher taxes provide disincentives to economic activity and can have negative effects in terms of economic welfare and growth.

The 1990s have shown that mobility, when it occurs to a significant extent, may actually not be wanted. When largely British, Irish, and Portuguese building workers competed successfully on the German labour market, the German authorities enacted a law which forces foreign workers working for foreign companies in Germany to be bound to the minimum wages that are agreed by German employers and unions through collective bargaining (Posted Workers Law (Entsendegesetz), see Eekhoff, 
1996; Koberski, Stahl, and Hold, 1997). The spirit of that law shows that free mobility of labour within the EU is not taken seriously. In the long run such policies by nation states are likely to increase the strains of monetary union, not lessen them.

\section{Policy Options}

There are indeed many things that could still be done to increase labour mobility in Europe. Here we identify four key points that we believe to be most effective (see also the Green Book by the European Commission, 1996). First, the harmonisation of professional degrees may be furthered. Second, tax systems can be harmonised. Third, one could better co-ordinate the social insurance system. At the moment, it is not possible to transfer rights to pensions and unemployment benefits without cost. A factor increasing the mobility of the unemployed would be to condition unemployment benefit entitlement on the readiness to accept a job in the entire EU, not just in the particular nation state the unemployed person is a citizen of. Fourth, a common language that is spoken and understood by all Europeans is essential for a large number of workers to move between nation states. All workers in the EU would therefore have to be fluent in one common language.

Clearly, if the four points just mentioned were implemented it would mean substantial changes to European societies. The changes would not only be economic but affect the society and culture in Europe's nation states profoundly. At the moment, issues like a common official language are not on the political agenda. Although knowledge of English is most often required in highly qualified jobs in Europe as well as in the rest of the world, the proposal to make English (or any other language) the official EU language will probably not find a majority in the near future. The harmonisation of the social security system also seems to be distant. Nevertheless, there can be no doubt that a significant increase in labour mobility requires such profound policy measures. 


\section{References}

Attanasio, O.P. and F. Padoa Schioppa (1991): Regional Inequalities, Migration and Mismatch in Italy, 1960-86, in: Padoa Schioppa, F. (ed.): Mismatch and Labour Mobility, Cambridge: Cambridge University Press, pp. 237-324.

Baddeley, M., R. Martin, and P. Tyler (1998): European Regional Unemployment Disparities: Convergence or Persistence?, European Urban and Regional Studies 5, pp. 195-215.

Barro, R.J. and X. Sala-i-Martin (1995): Economic Growth, New York: McGrawHill.

Bayoumi, T. and B. Eichengreen (1993): Shocking Aspects of European Monetary Integration, in: Torres, F., and F. Giavazzi (eds.): Adjustment and Growth in the European Monetary Union, Cambridge, pp. 193-229.

Boockmann, B. (1999): Trade Union Strategies and Labour Market Outcomes under EMU, ZEW Mannheim, mimeo.

Büttner, T. (1999a): Agglomeration, Growth, and Adjustment, A Theoretical and Empirical Study of Regional Labor Markets in Germany, Heidelberg: Physica/Springer, to appear in 1999 in the series ZEW Economic Studies.

Büttner, T. (1999b): Regional Stabilization by Fiscal Flows and the Need for Fiscal Equalization in EMU, ZEW Mannheim, mimeo.

Buscher, H.S. (1999): Business Cycles in EU Member Sates, ZEW Mannheim, mimeo.

Chies, L. (1994): Das Migrationsproblem in der Europäischen Gemeinschaft, Frankfurt a.M.: Europäischer Verlag der Wissenschaften.

Decressin, J.(1994): Internal Migration in West Germany and Implications for EastWest Salary Convergence, Weltwirtschaftliches Archiv 130: pp. 231-257.

Decressin, J. and A. Fatás (1995): Regional Labour Market Dynamics In Europe, European Economic Review 39, pp. 1627-1655.

De Grauwe, P. and W. Vanhaverbeke (1993): Is Europe an Optimum Currency Area?, in: Masson, P.R. and M.P. Taylor (eds.): Policy Issues in the Operation of Currency Unions, Cambridge: Cambridge University Press, pp. 111-129.

Eekhoff, J. (1996): Entsendegesetz - Eine Aushöhlung der Wirtschaftsordnung?, Zeitschrift für Wirtschaftsdpolitik 45, pp. 17-29. 
Eichengreen, B. (1993): Labor markets and European monetary unification, in: Masson, P.R. and M.P. Taylor (eds.): Policy Issues in the Operation of Currency Unions, Cambridge: Cambridge University Press, pp. 130-162.

European Commission (1996): Grünbuch - Bildung, Berufsbildung, Forschung, Hindernisse für die grenzüberschreitende Mobilität (also available in English), Brussels.

European Commission (1998): Beschäftigung in Europa 1997, Analyse von Schlüsselthemen, Beschäftigung und soziale Angelegenheiten (also available in English), Luxembourg.

Franz, W. (1998): Der Euro als Jobmaschine? Zu den Auswirkungen des Euro auf den Deutschen Arbeitsmarkt, IZA Discussion Paper No. 9, Bonn.

Funke, M. (1997): The Nature of Shocks in Europe and in Germany, Economica 64, pp. 461-469.

Gros, D. (1996): A Reconsideration of the Optimum Currency Area Approach: The Role of External Shocks and Labour Mobility, National Institute Economic Review 158, pp. 108-117.

Hausman, J.A. (1978): Specification Tests in Econometrics, Econometrica 46, pp. $1251-1271$.

Koberski, W., K.-H. Sahl, and D. Hold (1997): Arbeitnehmer-Entsendegesetz, München: Beck.

Lauer, C. (1999): The Effects of European Economic and Monetary Union on Wage Behaviour, ZEW Mannheim, mimeo.

Müller, C. and H.S. Buscher (1999a): The Impact of Monetary Instruments on Shock Absorption in EU-Countries, ZEW Mannheim, mimeo.

Müller, C. and H.S. Buscher (1999b): Exchange Rate Volatility Effects on the German Labour Market: A Survey of Recent Results and Extensions, ZEW Mannheim, mimeo.

Müller, C. and F. Heinemann (1999): Capital Mobility within EMU, ZEW Mannheim, mimeo.

Mundell, R.A. (1961): A Theory of Optimum Currency Areas, American Economic Review 51, pp. 509-516.

OECD (1986): Flexibility in the Labour Market, Paris.

Pissarides, C.A. and I. McMaster (1990): Regional Migration Wages and Unemployment: Empirical Evidence and Implications for Policy, Oxford Economic Papers 42, pp. 812-831. 
Straubhaar, T. (1988): International Labour Migration within a Common Market: Some Aspects of EC Experience, Journal of Common Market Studies 27: pp. 45-62.

Todaro, M.P. (1980): Internal Migration in Developing Countries: A Survey, in: Easterlin, R.A. (ed.): Population and Economic Change in Developing Countries, Chicago: Chicago University Press, pp. 361-402.

Velling, J. (1995): Immigration und Arbeitsmarkt, Eine empirische Analyse für die Bundesrepublik Deutschland, Schriftenreihe des ZEW, Band 6, 1995, BadenBaden: Nomos.

Weidlich, W. and G. Haag (eds.) (1988): Interregional Migration, Berlin/Heidelberg: Springer.

Zimmermann, K.F. (1995): Tackling the European Migration Problem, Journal of Economic Perspectives 9, pp. 45-62. 


\section{Appendix}

Figure 1: $\quad$ Map of Euroland's NUTS2 Regions
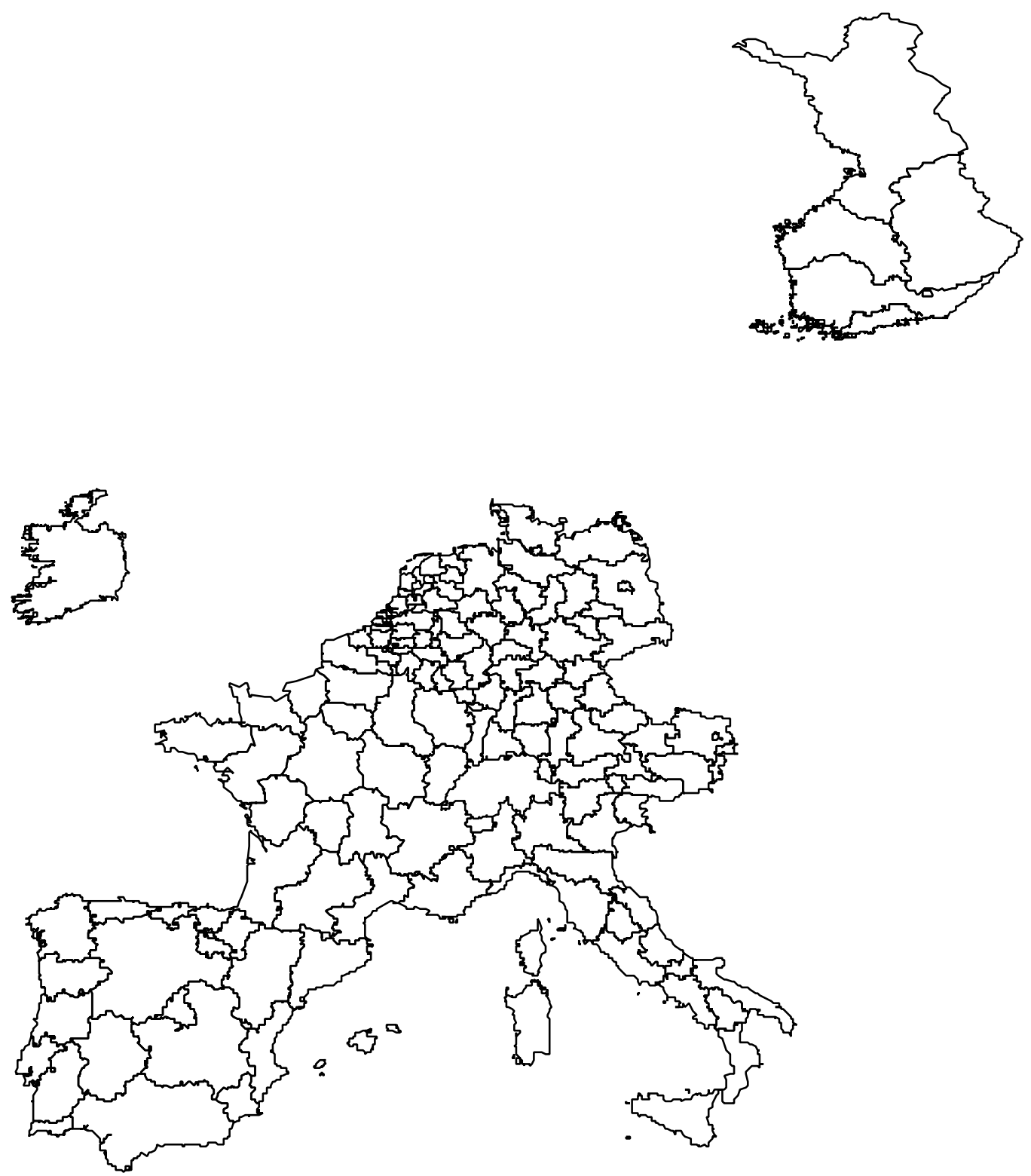
Figure 2: $\quad$ Migration-Induced Population Growth Factors - Western Germany

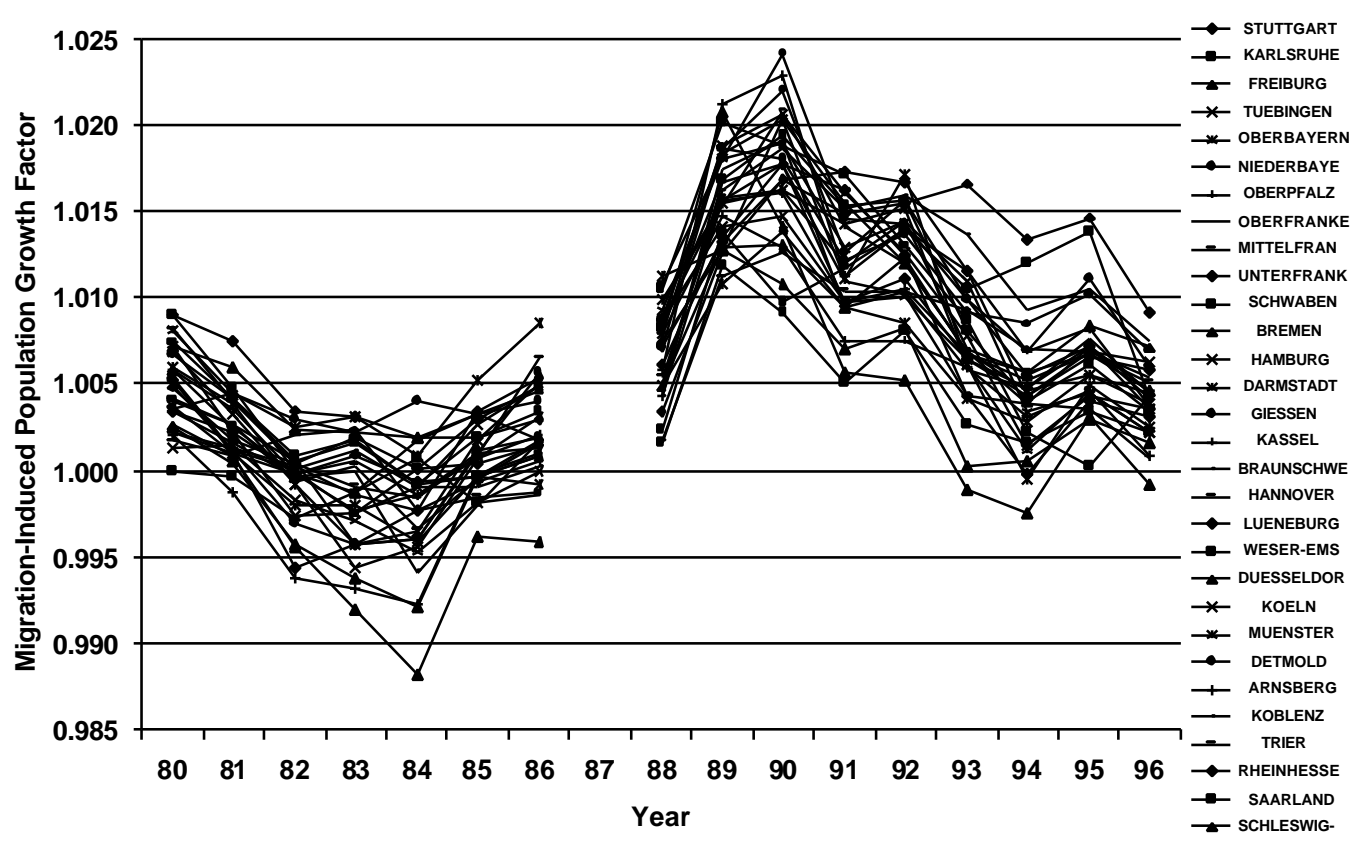

Notes: migration is net migration (total immigration - total emigration); the migration-induced population growth factor equals $\left(\mathrm{mig}_{i t}+\right.$ pop $\left._{i t-1}\right) /$ pop $_{i t-1}$.

Source: Regio 98 databank, Eurostat; own calculations. 
Figure 3: $\quad$ Migration-Induced Population Growth Factors - France

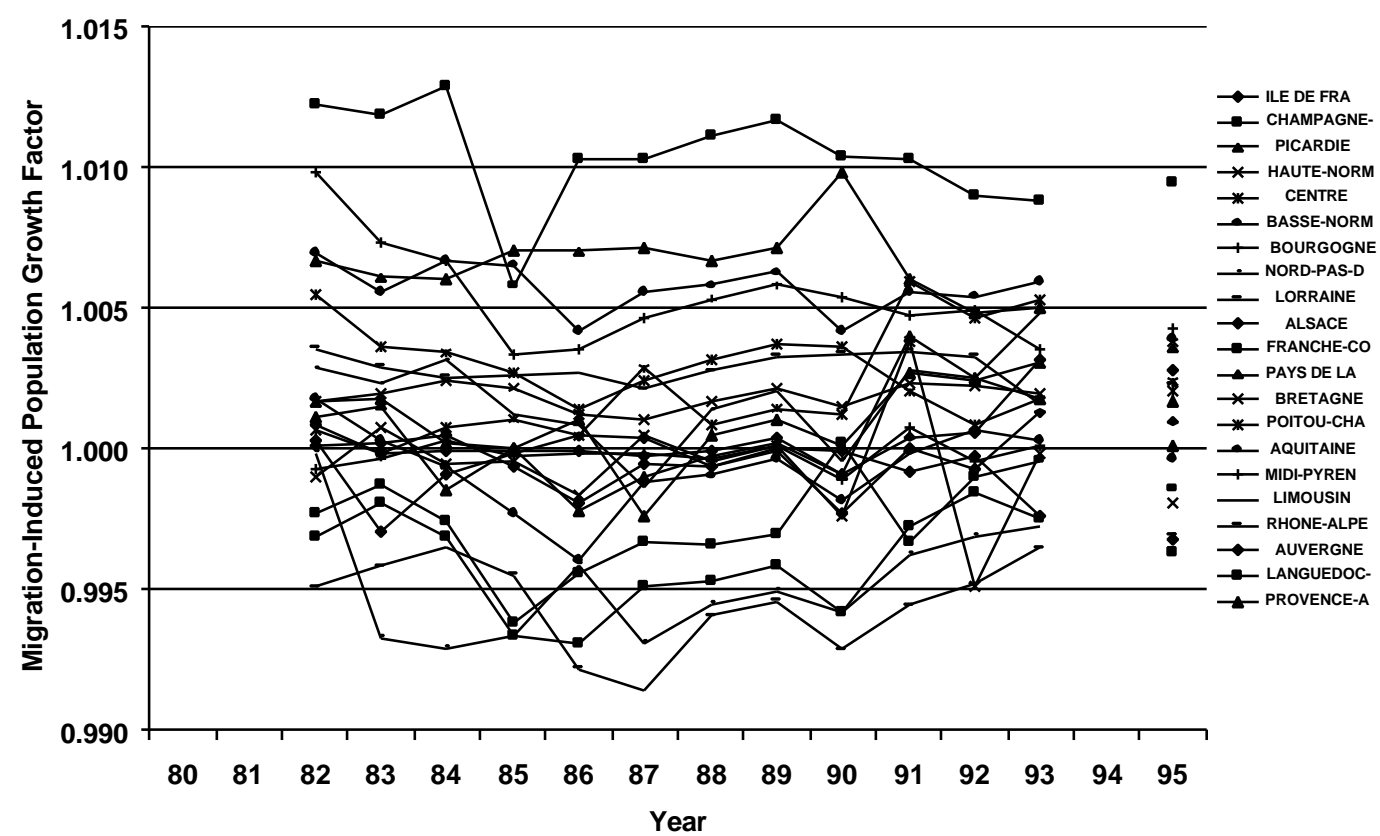

Notes: migration is net migration (total immigration - total emigration); the migration-induced population growth factor equals $\left(\mathrm{mig}_{i t}+\right.$ pop $\left._{i t-1}\right) /$ pop $_{i t-1}$;

the region 'Corse' has been left out in the calculations for France due an inconsistency in the time series of that region (information from Eurostat Luxembourg).

Source: Regio 98 databank, Eurostat; own calculations.

Figure 4: $\quad$ Migration-Induced Population Growth Factors - Italy (1)

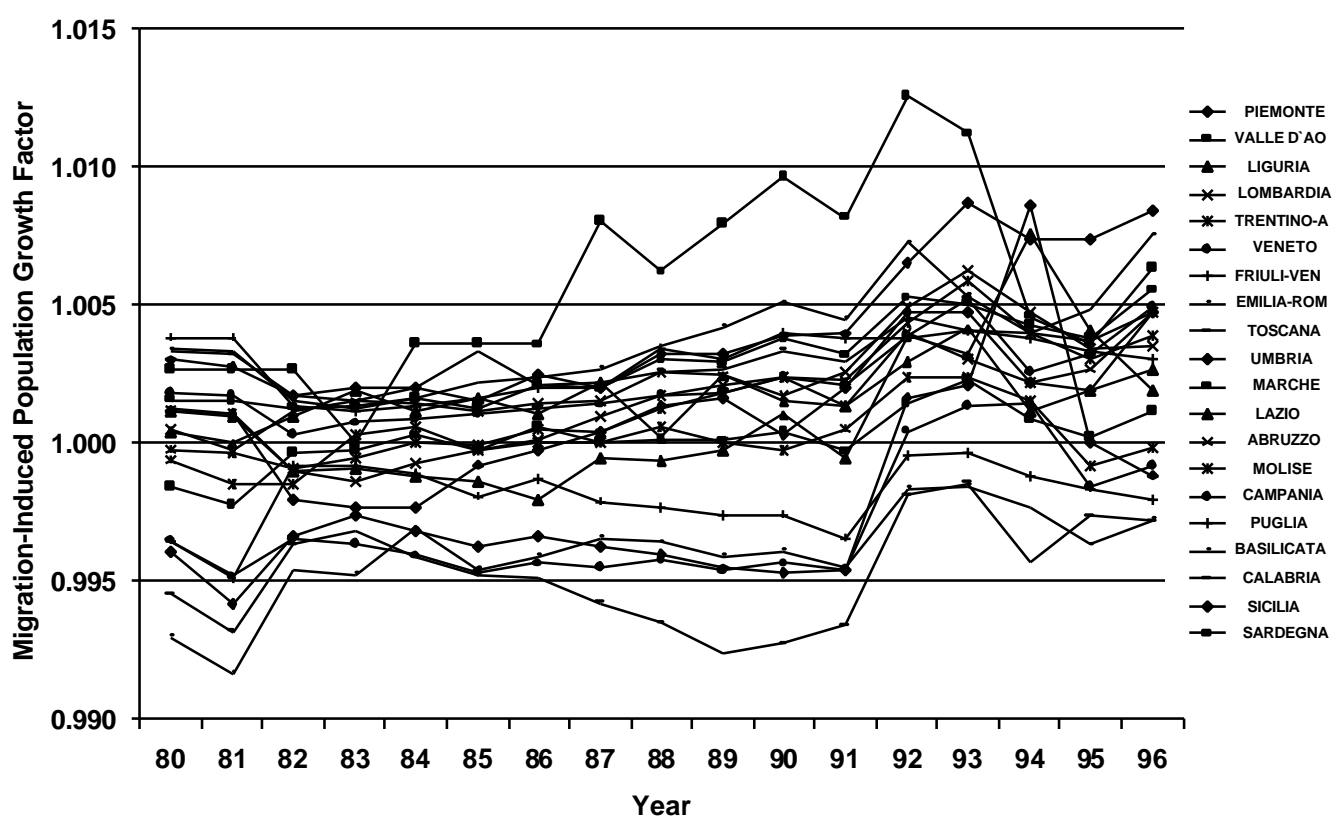

Notes: migration is net migration (total immigration - total emigration); the migration-induced population growth factor equals $\left(\mathrm{mig}_{i t}+\right.$ pop $\left._{i t-1}\right) /$ pop $_{i t-1}$.

Source: Regio 98 databank, Eurostat; own calculations. 
Figure 5: $\quad$ Internal Migration-Induced Population Growth Factors - Italy (2)

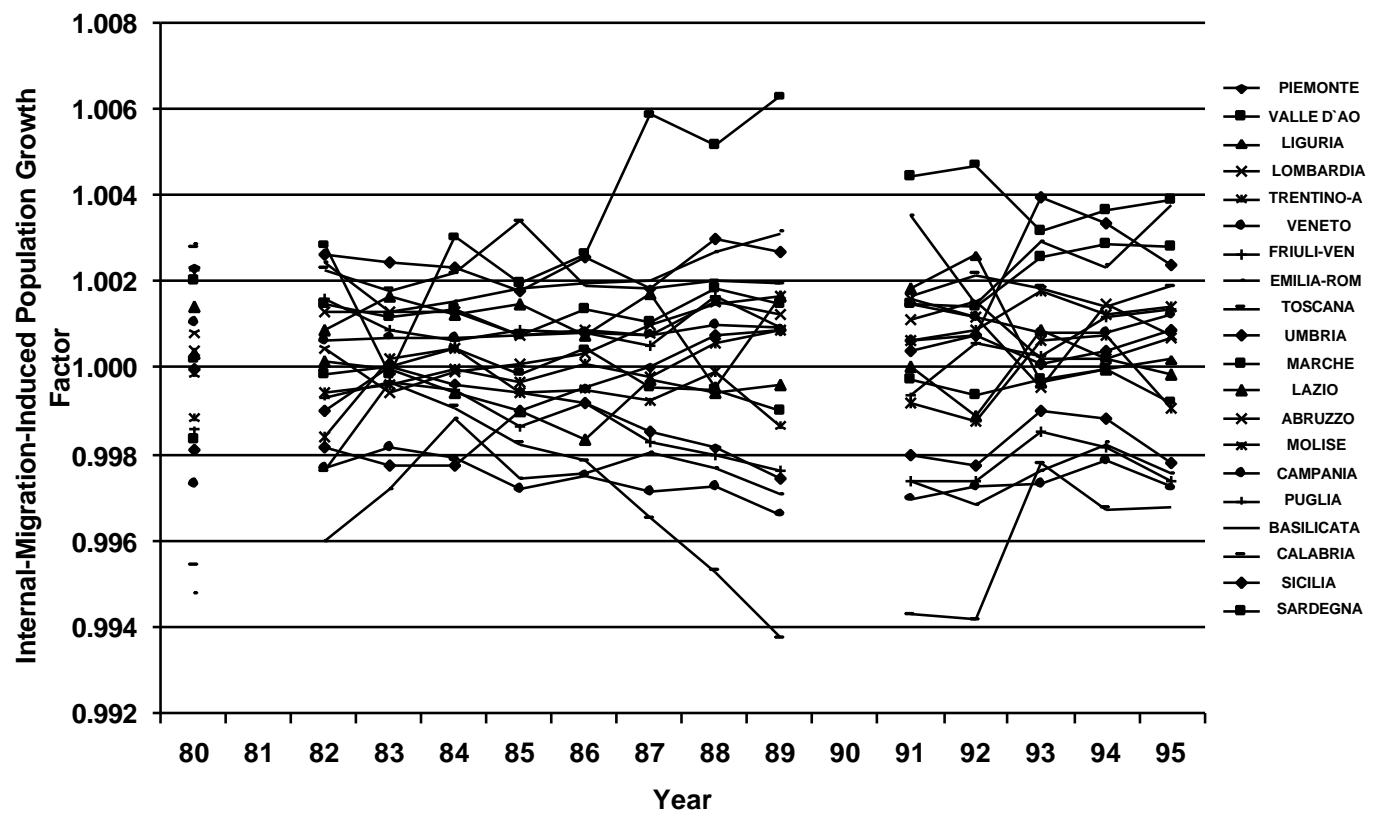

Notes: migration is net internal migration (total immigration from other Italian regions - total emigration to other Italian regions); the migration-induced population growth factor equals $\left(\mathrm{mig}_{i t}+\operatorname{pop}_{i t-1}\right) /$ pop $_{i t-1}$. Source: Regio 98 databank, Eurostat; own calculations. 
Figure 6: Coefficients of Variation in Unemployment Rates

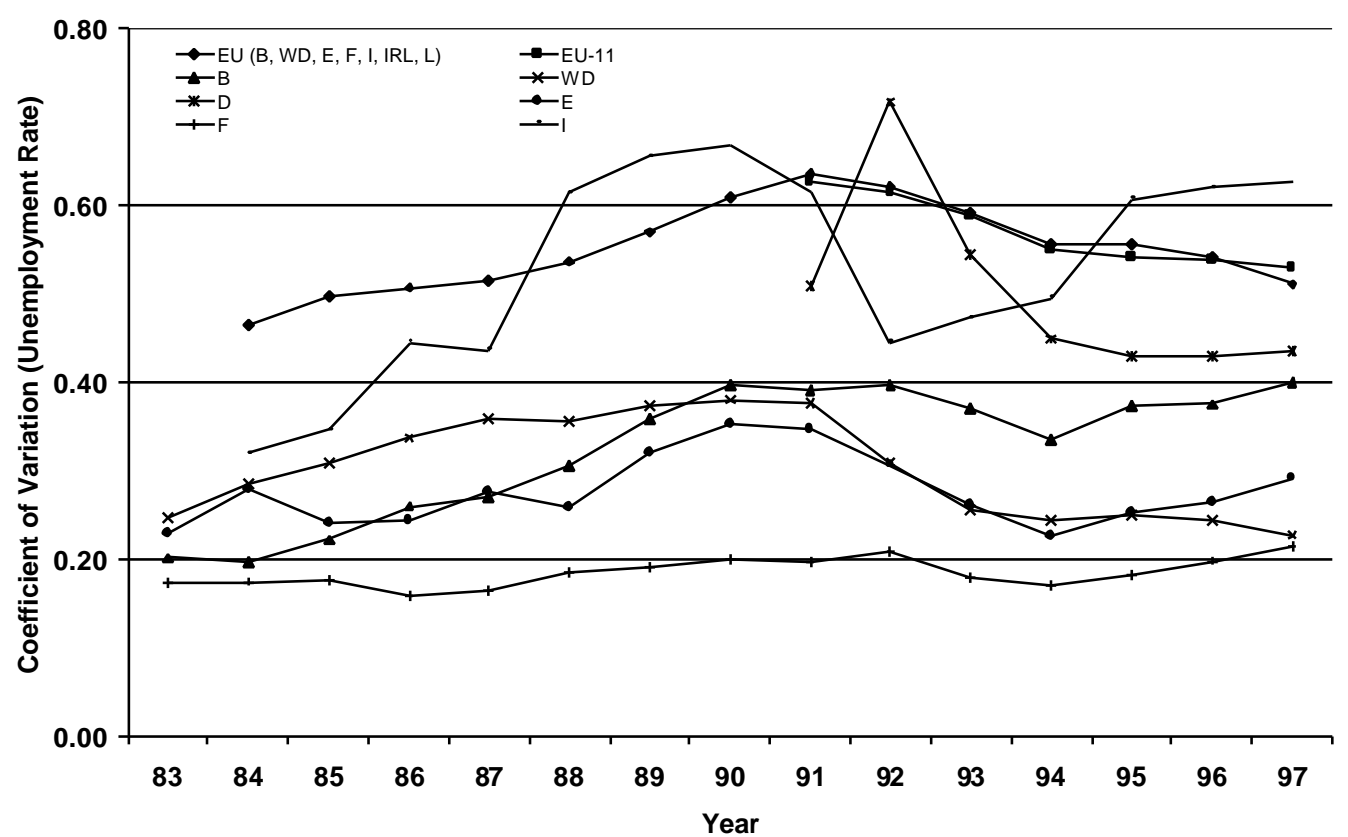

Note: The region 'Corse' has been left out in the calculations for France due an inconsistency in the time series of that region (information from Eurostat Luxembourg);

abbreviations: EU: European Union; B: Belgium; D: reunited Germany; WD: Western Germany; E: Spain; F: France; I: Italy; IRL: Ireland; L: Luxembourg; NL: Netherlands; SF: Finland.

Source: Regio 98 databank, Eurostat; own calculations.

\section{Figure 7: $\quad$ Coefficients of Variation in GDP in Purchasing Power Parities}

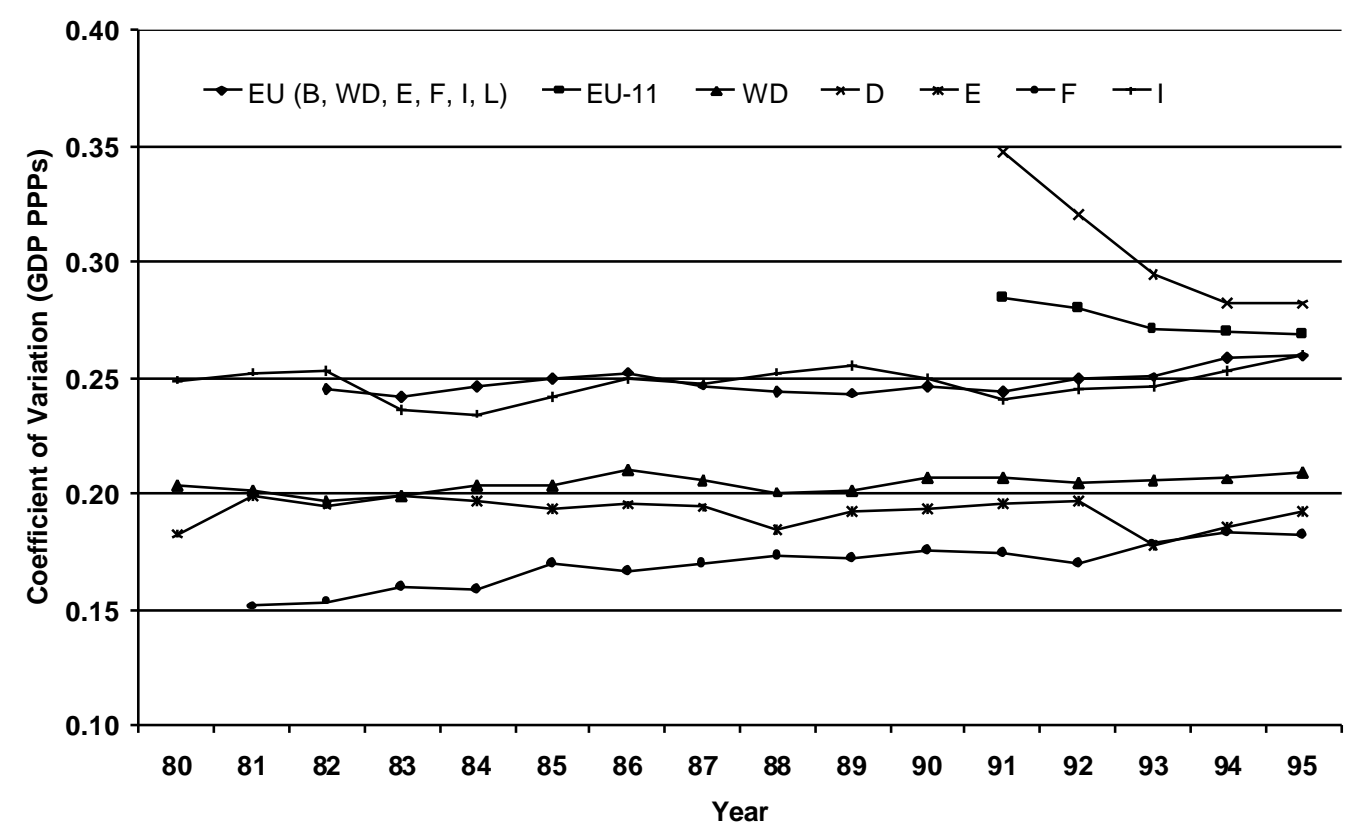

Notes: abbreviations: EU: European Union; EU-11: 'Euroland'; B: Belgium; D: reunited Germany; WD: Western Germany; E: Spain; F: France; I: Italy; L: Luxembourg.

Source: Regio 98 databank, Eurostat; own calculations. 
Table 4: Summary Statistics - Western Germany

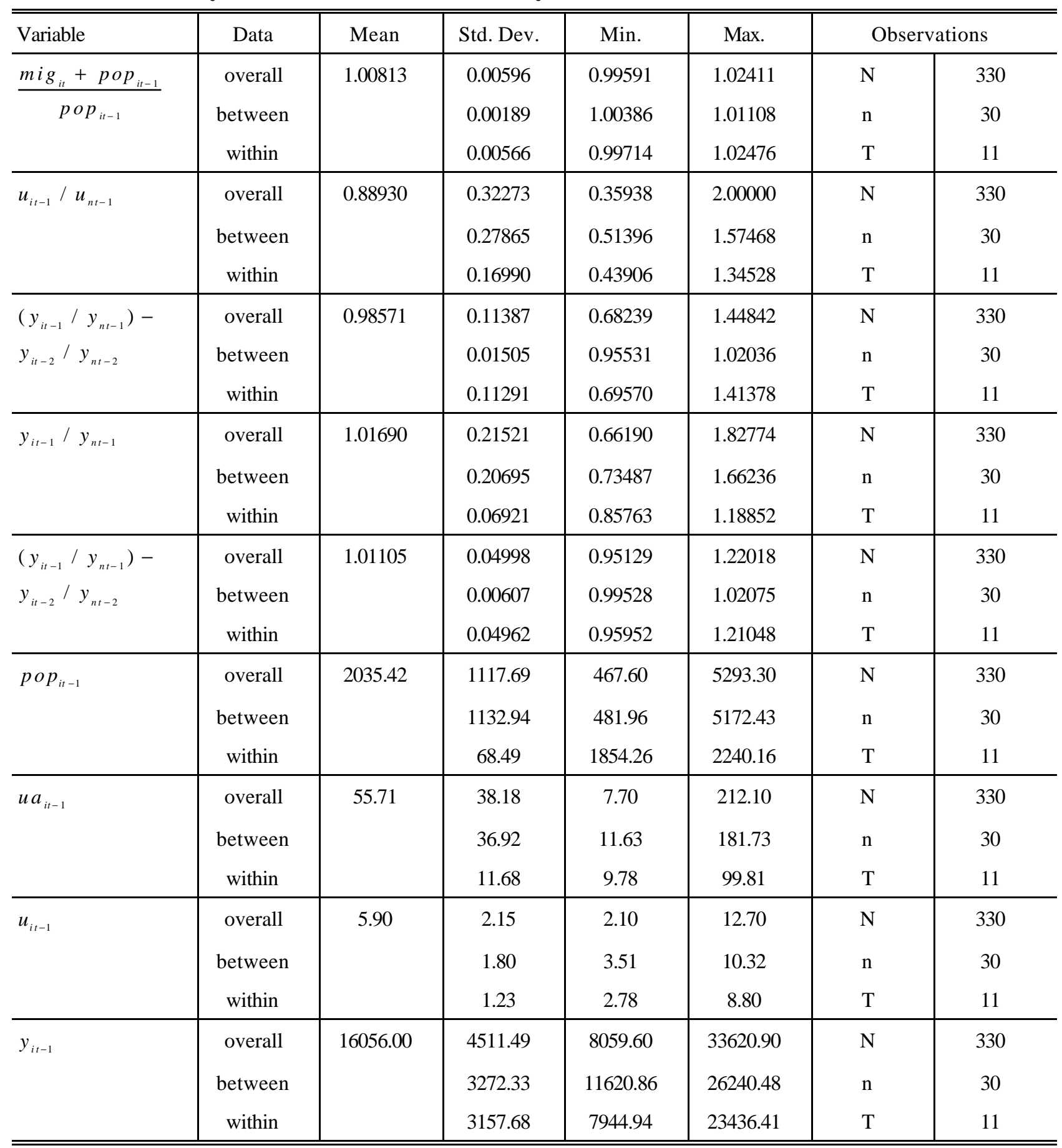

Notes: the between data are formed by calculating the means over time by region $\bar{x}_{i}$; the within data are defined as $x_{i t}-\bar{x}_{i .}+\overline{\bar{x}}$, where the overall mean $\overline{\bar{x}}$ is added to equate the mean of all data (overall, between, and within);

abbreviations: mig: migration in thousands; pop: population in thousands; $u$ : unemployment rate; $y$ : nominal GDP at purchasing power parities; ua: number of persons unemployed in thousands; $i$ : region indicator; $n$ : country indicator; $t$ : time period (year) indicator; $\mathrm{N}$ : total number of observations; $\mathrm{n}$ : number of regions; T: number of time periods (years);

migration is net migration (total immigration - total emigration);

population is measured at the beginning of each year; migration is measured in April of each year.

Source: Regio 98 databank, Eurostat; own calculations. 
Table 5: Summary Statistics - France

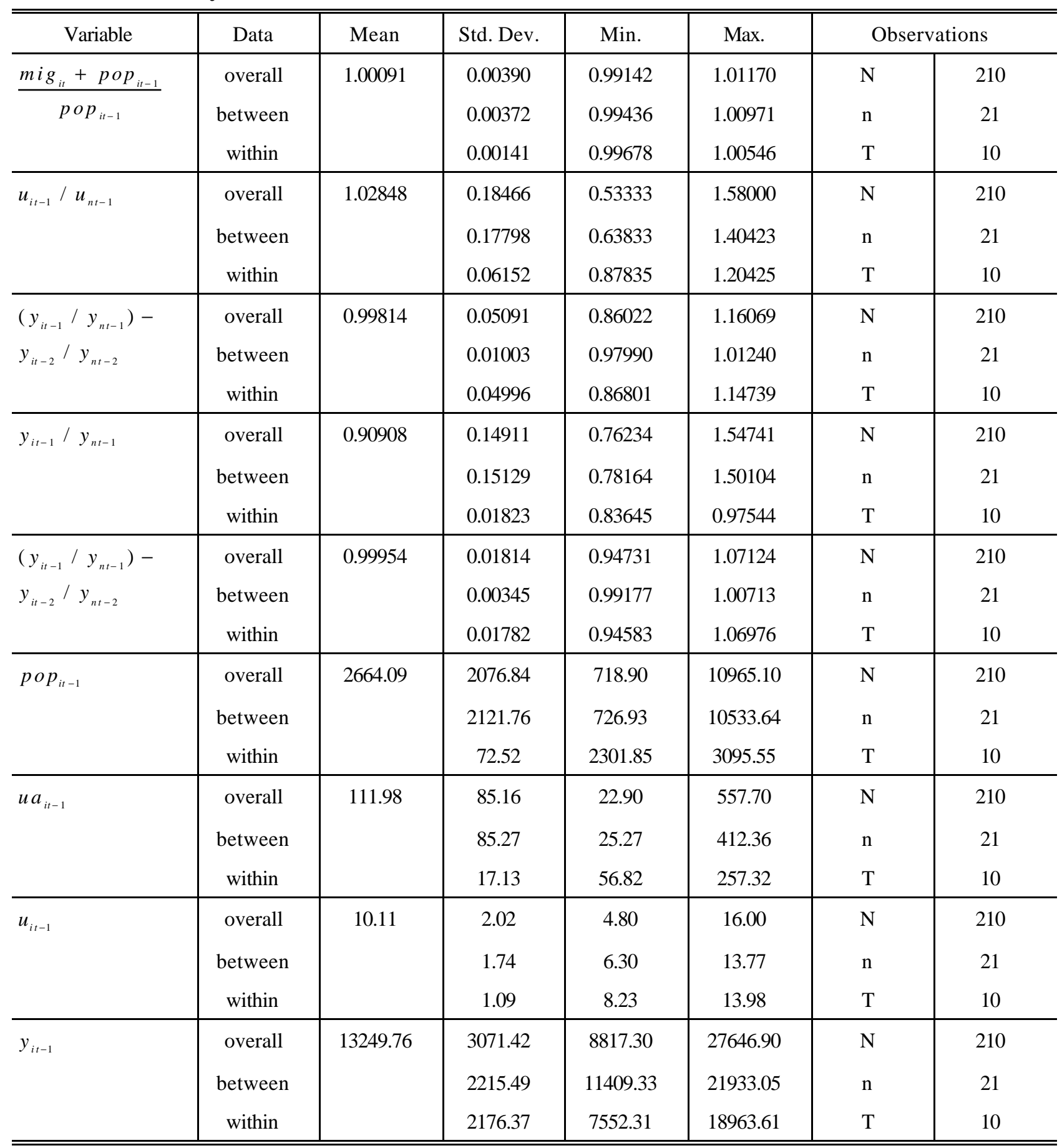

Notes: the between data are formed by calculating the means over time by region $\bar{x}_{i}$; the within data are defined as $x_{i t}-\bar{x}_{i .}+\overline{\bar{x}}$, where the overall mean $\overline{\bar{x}}$ is added to equate the mean of all data (overall, between, and within);

abbreviations: mig: migration in thousands; pop: population in thousands; $u$ : unemployment rate; $y$ : nominal GDP at purchasing power parities; ua: number of persons unemployed in thousands; $i$ : region indicator; $n$ : country indicator; $t$ : time period (year) indicator; $\mathrm{N}$ : total number of observations; $\mathrm{n}$ : number of regions; T: number of time periods (years);

migration is net migration (total immigration - total emigration); population is measured at the beginning of each year; migration is measured in April of each year; the region 'Corse' has been left out in the calculations for France due an inconsistency in the time series of that region (information from Eurostat Luxembourg). 
Source: Regio 98 databank, Eurostat; own calculations.

Table 6: Summary Statistics - Italy (1)

\begin{tabular}{|c|c|c|c|c|c|c|c|}
\hline Variable & Data & Mean & Std. Dev. & Min. & Max. & \multicolumn{2}{|c|}{ Observations } \\
\hline $\operatorname{mig}_{i t}+p o p_{i t-1}$ & \multirow{3}{*}{$\begin{array}{c}\text { overall } \\
\text { between } \\
\text { within }\end{array}$} & \multirow[t]{3}{*}{1.00143} & 0.00345 & 0.99236 & 1.01250 & $\mathrm{~N}$ & 239 \\
\hline \multirow[t]{2}{*}{$p o p_{i t-1}$} & & & 0.00300 & 0.99527 & 1.00741 & $\mathrm{n}$ & 20 \\
\hline & & & 0.00185 & 0.99756 & 1.01145 & $\bar{T}$ & 11.95 \\
\hline \multirow[t]{3}{*}{$u_{i t-1} / u_{n t-1}$} & \multirow{3}{*}{$\begin{array}{c}\text { overall } \\
\text { between } \\
\text { within }\end{array}$} & \multirow[t]{3}{*}{1.02429} & 0.53488 & 0.23333 & 2.32000 & $\mathrm{~N}$ & 239 \\
\hline & & & 0.52104 & 0.40433 & 1.92286 & $\mathrm{n}$ & 20 \\
\hline & & & 0.16622 & 0.37943 & 1.50107 & $\bar{T}$ & 11.95 \\
\hline \multirow{3}{*}{$\begin{array}{l}\left(y_{i t-1} / y_{n t-1}\right)- \\
y_{i t-2} / y_{n t-2}\end{array}$} & \multirow{3}{*}{$\begin{array}{c}\text { overall } \\
\text { between } \\
\text { within }\end{array}$} & \multirow[t]{3}{*}{1.00536} & 0.17100 & 0.54688 & 2.02128 & $\mathrm{~N}$ & 239 \\
\hline & & & 0.02861 & 0.96783 & 1.07113 & $\mathrm{n}$ & 20 \\
\hline & & & 0.16869 & 0.48111 & 1.97618 & $\bar{T}$ & 11.95 \\
\hline \multirow[t]{3}{*}{$y_{i t-1} / y_{n t-1}$} & \multirow{3}{*}{$\begin{array}{c}\text { overall } \\
\text { between } \\
\text { within }\end{array}$} & \multirow[t]{3}{*}{0.97204} & 0.23557 & 0.56052 & 1.32365 & $\mathrm{~N}$ & 239 \\
\hline & & & 0.24082 & 0.58439 & 1.29620 & $\mathrm{n}$ & 20 \\
\hline & & & 0.01839 & 0.91365 & 1.04852 & $\bar{T}$ & 11.95 \\
\hline \multirow{3}{*}{$\begin{array}{l}\left(y_{i t-1} / y_{n t-1}\right)- \\
y_{i t-2} / y_{n t-2}\end{array}$} & \multirow{3}{*}{$\begin{array}{c}\text { overall } \\
\text { between } \\
\text { within }\end{array}$} & \multirow[t]{3}{*}{1.00050} & 0.01890 & 0.93075 & 1.08787 & $\mathrm{~N}$ & 239 \\
\hline & & & 0.00441 & 0.99367 & 1.01085 & $\mathrm{n}$ & 20 \\
\hline & & & 0.01840 & 0.92841 & 1.08552 & $\bar{T}$ & 11.95 \\
\hline \multirow[t]{3}{*}{ pop $p_{i t-1}$} & \multirow{3}{*}{$\begin{array}{c}\text { overall } \\
\text { between } \\
\text { within }\end{array}$} & \multirow[t]{3}{*}{2849.85} & 2219.55 & 112.50 & 8910.50 & $\mathrm{~N}$ & 239 \\
\hline & & & 2274.71 & 114.95 & 8853.28 & $\mathrm{n}$ & 20 \\
\hline & & & 28.75 & 2755.15 & 2986.75 & $\bar{T}$ & 11.95 \\
\hline \multirow[t]{3}{*}{$u a_{i t-1}$} & \multirow{3}{*}{$\begin{array}{c}\text { overall } \\
\text { between } \\
\text { within }\end{array}$} & \multirow[t]{3}{*}{115.99} & 106.76 & 1.00 & 523.90 & $\mathrm{~N}$ & 239 \\
\hline & & & 105.79 & 2.15 & 403.46 & $\mathrm{n}$ & 20 \\
\hline & & & 27.05 & 7.14 & 236.44 & $\bar{T}$ & 11.95 \\
\hline \multirow[t]{3}{*}{$u_{i t-1}$} & \multirow{3}{*}{$\begin{array}{c}\text { overall } \\
\text { between } \\
\text { within }\end{array}$} & \multirow[t]{3}{*}{10.29} & 5.47 & 2.10 & 25.60 & $\mathrm{~N}$ & 239 \\
\hline & & & 5.23 & 4.12 & 19.29 & $\mathrm{n}$ & 20 \\
\hline & & & 1.99 & 3.30 & 16.76 & $\bar{T}$ & 11.95 \\
\hline \multirow[t]{3}{*}{$y_{i t-1}$} & \multirow{3}{*}{$\begin{array}{l}\text { overall } \\
\text { between } \\
\text { within }\end{array}$} & \multirow[t]{3}{*}{13708.86} & 4245.53 & 5802.90 & 22975.30 & $\mathrm{~N}$ & 239 \\
\hline & & & 3433.26 & 8214.53 & 18512.46 & $\mathrm{n}$ & 20 \\
\hline & & & 2613.25 & 8168.89 & 19252.76 & $\bar{T}$ & 11.95 \\
\hline
\end{tabular}

Notes: the between data are formed by calculating the means over time by region $\bar{x}_{i}$; the within data are defined as $x_{i t}-\bar{x}_{i .}+\overline{\bar{x}}$, where the overall mean $\overline{\bar{x}}$ is added to equate the mean of all data (overall, between, and within);

abbreviations: mig: migration in thousands; pop: population in thousands; $u$ : unemployment rate; $y$ : nominal GDP at purchasing power parities; ua: number of persons unemployed in thousands; $i$ : region indicator; $n$ : country indicator; $t$ : time period (year) indicator; $\mathrm{N}$ : total number of observations; $\mathrm{n}$ : number of regions; $\bar{T}$ : average number of time periods (years);

migration is net migration (total immigration - total emigration);

population is measured at the beginning of each year; migration is measured in April of each year. 
Source: Regio 98 databank, Eurostat; own calculations. 
Table 7: Summary Statistics - Italy (2)

\begin{tabular}{|c|c|c|c|c|c|c|c|}
\hline \multirow{2}{*}{$\begin{array}{l}\text { Variable } \\
\frac{m i g_{i t}+p o p_{i t-1}}{}\end{array}$} & \multirow{2}{*}{$\frac{\text { Data }}{\text { overall }}$} & \multirow{2}{*}{$\frac{\text { Mean }}{1.00021}$} & \multirow{2}{*}{$\frac{\text { Std. Dev. }}{0.00209}$} & \multirow{2}{*}{$\frac{\text { Min. }}{0.99375}$} & \multirow{2}{*}{$\frac{\text { Max. }}{1.00627}$} & \multicolumn{2}{|c|}{ Observations } \\
\hline & & & & & & $\mathrm{N}$ & 199 \\
\hline \multirow{2}{*}{$p o p_{i t-1}$} & between & & 0.00202 & 0.99614 & 1.00442 & $\mathrm{n}$ & 20 \\
\hline & within & & 0.00074 & 0.99782 & 1.00231 & $\bar{T}$ & 9.95 \\
\hline \multirow[t]{3}{*}{$u_{i t-1} / u_{n t-1}$} & overall & 1.02216 & 0.52088 & 0.23333 & 2.23333 & $\mathrm{~N}$ & 199 \\
\hline & between & & 0.50434 & 0.39892 & 1.87628 & $\mathrm{n}$ & 20 \\
\hline & within & & 0.17084 & 0.39825 & 1.51989 & $\bar{T}$ & 9.95 \\
\hline \multirow{3}{*}{$\begin{array}{l}\left(y_{i t-1} / y_{n t-1}\right)- \\
y_{i t-2} / y_{n t-2}\end{array}$} & overall & 1.01020 & 0.18176 & 0.54688 & 2.02128 & $\mathrm{~N}$ & 199 \\
\hline & between & & 0.02665 & 0.97383 & 1.08335 & $\mathrm{n}$ & 20 \\
\hline & within & & 0.17988 & 0.47373 & 1.97743 & $\bar{T}$ & 9.95 \\
\hline \multirow[t]{3}{*}{$y_{i t-1} / y_{n t-1}$} & overall & 0.97136 & 0.23362 & 0.56052 & 1.31623 & $\mathrm{~N}$ & 199 \\
\hline & between & & 0.23890 & 0.58408 & 1.29377 & $\mathrm{n}$ & 20 \\
\hline & within & & 0.01707 & 0.92302 & 1.03211 & $\bar{T}$ & 9.95 \\
\hline \multirow{3}{*}{$\begin{array}{l}\left(y_{i t-1} / y_{n t-1}\right)- \\
y_{i t-2} / y_{n t-2}\end{array}$} & overall & 1.00065 & 0.01934 & 0.93075 & 1.08787 & $\mathrm{~N}$ & 199 \\
\hline & between & & 0.00478 & 0.98963 & 1.00787 & $\mathrm{n}$ & 20 \\
\hline & within & & 0.01877 & 0.92723 & 1.08435 & $\bar{T}$ & 9.95 \\
\hline \multirow[t]{3}{*}{$p o p_{i t-1}$} & overall & 2850.22 & 2217.99 & 112.50 & 8901.00 & $\mathrm{~N}$ & 199 \\
\hline & between & & 2272.69 & 114.69 & 8850.01 & $\mathrm{n}$ & 20 \\
\hline & within & & 26.30 & 2767.55 & 2962.05 & $\bar{T}$ & 9.95 \\
\hline \multirow[t]{3}{*}{$u a_{i t-1}$} & overall & 114.18 & 103.22 & 1.00 & 523.90 & $\mathrm{~N}$ & 199 \\
\hline & between & & 102.29 & 2.06 & 388.23 & $\mathrm{n}$ & 20 \\
\hline & & & 26.03 & 20.55 & 249.85 & $\bar{T}$ & 9.95 \\
\hline \multirow[t]{3}{*}{$u_{i t-1}$} & overall & 10.08 & 5.19 & 2.10 & 23.00 & $\mathrm{~N}$ & 199 \\
\hline & between & & 4.95 & 3.98 & 18.46 & $\mathrm{n}$ & 20 \\
\hline & within & & 1.90 & 3.60 & 16.40 & $\bar{T}$ & 9.95 \\
\hline \multirow[t]{3}{*}{$y_{i t-1}$} & overall & 13353.82 & 4130.39 & 5802.90 & 21947.50 & $\mathrm{~N}$ & 199 \\
\hline & between & & 3322.41 & 8000.08 & 18108.96 & $\mathrm{n}$ & 20 \\
\hline & within & & 2565.42 & 8312.80 & 18261.47 & $\bar{T}$ & 9.95 \\
\hline
\end{tabular}

Notes: the between data are formed by calculating the means over time by region $\bar{x}_{i}$; the within data are defined as $x_{i t}-\bar{x}_{i .}+\overline{\bar{x}}$, where the overall mean $\overline{\bar{x}}$ is added to equate the mean of all data (overall, between, and within);

abbreviations: mig: migration in thousands; pop: population in thousands; $u$ : unemployment rate; $y$ : nominal GDP at purchasing power parities; ua: number of persons unemployed in thousands; $i$ : region indicator; $n$ : country indicator; $t$ : time period (year) indicator; $\mathrm{N}$ : total number of observations; $\mathrm{n}$ : number of regions; $\bar{T}$ : average number of time periods (years);

migration is net internal migration (total immigration from other Italian regions - total emigration to other Italian regions);

population is measured at the beginning of each year; migration is measured in April of each year. 
Source: Regio 98 databank, Eurostat; own calculations. 